\title{
Anti Reverse Transcriptase and Anticancer activity of stem ethanol extracts of Excoecaria agallocha (Euphorbiaceae)
}

\author{
R. C. Patil ${ }^{1}$, Sonal M. Manohar ${ }^{2}$, Madhav V. Upadhye ${ }^{2 *}$, V.I. Katchi ${ }^{3}$, Asha J. Rao ${ }^{3}$, Abhishek Mule ${ }^{1}$ \\ and Alpana S. Moghe ${ }^{4}$
}

\begin{abstract}
${ }^{1}$ Department of Microbiology, Bhavan's College, Andheri (W), Mumbai- 400058, Maharashtra, India. ${ }^{2}$ Department of Life Sciences, University of Mumbai, Santacruz (E), Mumbai-400098, Maharashtra, India. ${ }^{3}$ Department of Zoology, Bhavan's College, Andheri (W), Mumbai-400058, Maharashtra, India. ${ }^{4}$ Department of Cell and Molecular Biology, Rajeev Gandhi Institute of IT and Biotechnology, Bharthi Vidyapeeth University, Pune-411046, Maharashtra, India.
\end{abstract} Accepted 05 October 2011

\begin{abstract}
Excoecaria agallocha $\mathrm{L}$. (Euphorbiaceae) is a mangrove plant widely used in folklore medicine for the treatment of several diseases. In the present study anti HIV and anticancer properties of active fraction of stem ethanol extracts of the plant were investigated. The fraction showed significant anti-reverse transcriptase activity in the enzyme-based direct binding assay which was as good as that of the standard synthetic inhibitor. Anticancer activity of the same fraction was determined using MTS in vitro assay. It showed potent cytotoxicity against pancreatic cancer cell lines Capan-1 and Miapaca-2 with $\mathrm{IC}_{50}$ values of $4 \mu \mathrm{g} / \mathrm{ml}$ and $7 \mu \mathrm{g} / \mathrm{ml}$ respectively. These results clearly indicate strong anti HIV and anticancer properties in stem extracts of E. agallocha.
\end{abstract}

Key words: mangrove, pancreatic cancer, activity guided fractionation, anti HIV properties

\section{INTRODUCTION}

Natural products, especially form plants, have been used for the treatment of various diseases for thousands of years. Countries such as Egypt, China, India and Greece have practiced use of plants as medicines from ancient times and an impressive number of modern drugs have been developed from them (Shoeb, 2006). Over the past decade, substantial progress has been made in defining strategies for the safe and effective treatment of human immunodeficiency virus (HIV) infection, the cause of acquired immunodeficiency syndrome (AIDS) (Pengsuparp et al., 1995). Because reverse transcriptase (RT) is required for early proviral DNA synthesis, inhibition of the RT-catalyzed polymerization of DNA from viral RNA inhibits virus replication. The only drugs approved for use in HIV-1 infection to date are azidothymidine (AZT), didanosine (dideoxyinosine or $\mathrm{ddI}$ ), and zalcitabine (dideoxycytidine or ddC) (Pengsuparp et al., 1994). Although these compounds have been shown to benefit HIV infected individuals, there are toxic side effects associated with their use, and complete inhibition of viral replication is rarely achieved. Also, continuous therapy with these drugs leads to drug-resistant strains of the virus (Mekkawy et al., 2002). Natural products serve as one source of structurally novel chemicals and are expected to be fruitful for investigation as specific inhibitors of HIV RT. There are numerous reports available on isolation and characterization of bioactive compounds from plants having reverse transcriptase inhibiting activity (Pengsuparp et al., 1996; Sun et al., 1996; Lin et al., 1997).

Pancreatic cancer is considered to be one of the leading causes of cancer related deaths in developed countries and it is on the rise in developing countries like India. The disease is notoriously difficult to diagnose in its early stages. Conventional treatment using chemotherapy and radiation has only little effect in pancreatic cancer and the only potentially curative treatment is surgery (Michaud, 2004). Thus, there is an urgent need to develop new and effective strategies for the prevention and treatment for this form of cancer.

Plant derived compounds have also played an important role in the development of several clinically useful anticancer agents. These include vinblastine, vincristine, campothecin derivativestopotecan and irinotecan, etoposide and paclitaxel (Cragg and Newman, 2005; Cochrane et al., 2008). The anticancer properties of these are related to the regulation of cancer-related

*Corresponding author's email: madhavupadhye@gmail.com 
gene expression, induction of apoptosis, cell cycle arrest and/or DNA fragmentation and inhibition of different cellular enzymes (Upur et al., 2008). Hence, screening and isolation of active components from the herbs possessing anticancer potential appears to be a promising way of discovering novel therapeutic compounds.

Mangroves are salt tolerant forest ecosystems found mainly in tropical and sub-tropical intertidal regions. These rich ecosystems provide a wide range of ecological and economic products and services, and also support a variety of other coastal and marine ecosystems. Today mangroves are found in about 30 countries in tropical subtropical regions covering an area of about 99,300 $\mathrm{km}^{2}$ (Singh, 2000). Asia has the largest extent of mangroves (5.8 million hectares) accounting for some $38 \%$ of the global mangrove area. Five of the ten countries with the largest extent of mangroves worldwide are found in this region (FAO, 2007).

Excoecaria agallocha L. (Euphorbiaceae) is a small mangrove tree found extensively on seashores and edge-mangroves throughout tropical Africa, Asia, and northwest Australia. The plant has been used in traditional medicine against rheumatism, leprosy, epilepsy, paralysis, conjunctivitis and dermatitis (Jayaweera, 1980; UNESCO, 1981; Prakash et al., 1983; Wiriyachitra et al., 1985; Bandarnayake, 1998; 2002; Ghani, 2003) and for as a dart and fish poison (Ohigashi et al., 1974). The plant is reported to have anti HIV (Erickson et al., 1995), antinoceptive (Subhan et al., 2008a), anti microbial (Subhan et al., 2008b; Vadlapudi et al., 2009; Ravikumar et al., 2010), anti oxidant (Subhan et al., 2008c), anti-ulcer (Thirunavukkarasu et al., 2009) and anti filarial properties (Patra et al., 2009). Clinical trials carried out on this plant suggest that the plant possesses anti-bacterial, anti-HIV, anti-cancer and anti-viral properties (Morgany et al., 1999; Subhan et al., 2008a). Hence, the present study was carried out for the assessment of its anti reverse transcriptase and anti-cancer activity and comparing the same with standard drugs.

\section{MATERIALS AND METHODS}

\section{Preparation of plant extract}

Stems of E. agallocha were collected near Ratnagiri (Latitude 17.072/ longitude 73.668) coast from the state of Maharashtra, India. Care was taken to select only healthy, fresh, growing stem parts of about 10-15 mm diameter. Very young, delicate twigs and very hard and old stem parts were avoided. The plant material was identified and authenticated by Dr. B.L. Jadhav of the Dept. of Life Sciences University of Mumbai, an expert taxonomist of mangroves. The collected plant material was brought to the laboratory, washed thoroughly under running tap water in order to remove dirt, and other contaminants from the sample. Stems of $E$. agallocha were then oven dried at $40^{\circ} \mathrm{C}$ to reduce the moisture content, ground thoroughly in to a powder with the help of mortar and pestle. The powder was carefully sieved through muslin cloth. The stem powder (10 g) was used to prepare hot extracts of E. agallocha using soxhlet extraction method with ethanol $(200 \mathrm{ml})$ as solvent. The extract was evaporated on a rotary evaporator to remove the solvent completely and reduce the volume of $20 \mathrm{ml}$ $(50 \% \mathrm{w} / \mathrm{v})$. The resultant dark reddish green gummy mass was then stored in airtight bottles and kept at $4^{\circ} \mathrm{C}$ till further use.

\section{Fractionation}

Stem ethanol extract of E. agallocha that showed significant antioxidant and antibacterial activity previously (Subhan et al., 2008b; Subhan et al., 2008c) was subjected to bioactivity guided fractionation study. Fig.1 gives the flow chart employed for fractionation of stem ethanol extract. Soxhlet ethanol stem extract was evaporated to dryness in a Rotary evaporator and the residues collected were serially dissolved in different solvents ranging from non-polar to polar (petroleum ether, chloroform, benzene, ethyl acetate, acetone, ethanol and methanol) with centrifugation at $3000 \mathrm{rpm}$ and filtration at intervals. The selection of these solvents was according to the Eluotropic series suggested by Trappe (Kirchner, 1978). The fractions obtained were designated as fraction ' $a$ ' to fraction ' $g$ ' from non-polar to polar respectively. All the fractions were checked for possible antimicrobial activity on the test organisms and only fractions exhibiting potent bioactivity was subjected to anti reverse transcriptase activity and anticancer activity assays.

\section{Test microorganisms and media}

Seven standard human pathogens comprising five bacteria and two fungi were procured from the National Chemical laboratory (NCL), Pune, India. The organisms were maintained on slants of their respective media as indicated in Table 1 and stored at $4^{\circ} \mathrm{C}$ with periodic sub-culturing. 
Bioassay of fractions of E. agallocha (In vitro antimicrobial assay)

All the fractions of E. agallocha stem extract were evaluated for the bioassay test against the test organisms by Agar cup method (Spooner and Sykes, 1972). To $20 \mathrm{ml}$ of the sterile nutrient medium, $0.6 \mathrm{ml}$ of test culture was added and poured into the plate, slowly shaken to mix the culture and medium thoroughly and were kept on a plane surface. After solidification four wells were made with the help of a flame sterilized stainless steel cork borer $(8 \mathrm{~mm})$. In to one of the wells, $80 \mu \mathrm{l}$ of solvent was added as negative control while a similar quantity of standard antibiotic Ampicillin and Kanamycin were added as positive control at a concentration of $10 \mathrm{mg} / \mathrm{ml}$. Into the other two wells, $80 \mu \mathrm{l}$ fractions of stem extract were loaded using a micropipette and kept for diffusion at $4{ }^{\circ} \mathrm{C}$ for 20 $\mathrm{min}$, and the plates were incubated at required temperature for $24 \mathrm{~h}$.

\section{Anti reverse transcriptase activity assay}

Ethanol fraction of stem extracts was obtained through activity-guided fractionation and was tested for possible inhibition of HIV reverse transcriptase. The assays were carried out at Haffkine Research Institute, Parel, Mumbai according to the method of Pengsuparp et al., (1994). The median inhibitory concentration was calculated from a linearly regressed dose response plot of percent control activity vs. concentration of compound, utilizing at least five concentrations of the test compound. Results were compared with a standard drug i.e. AZT.

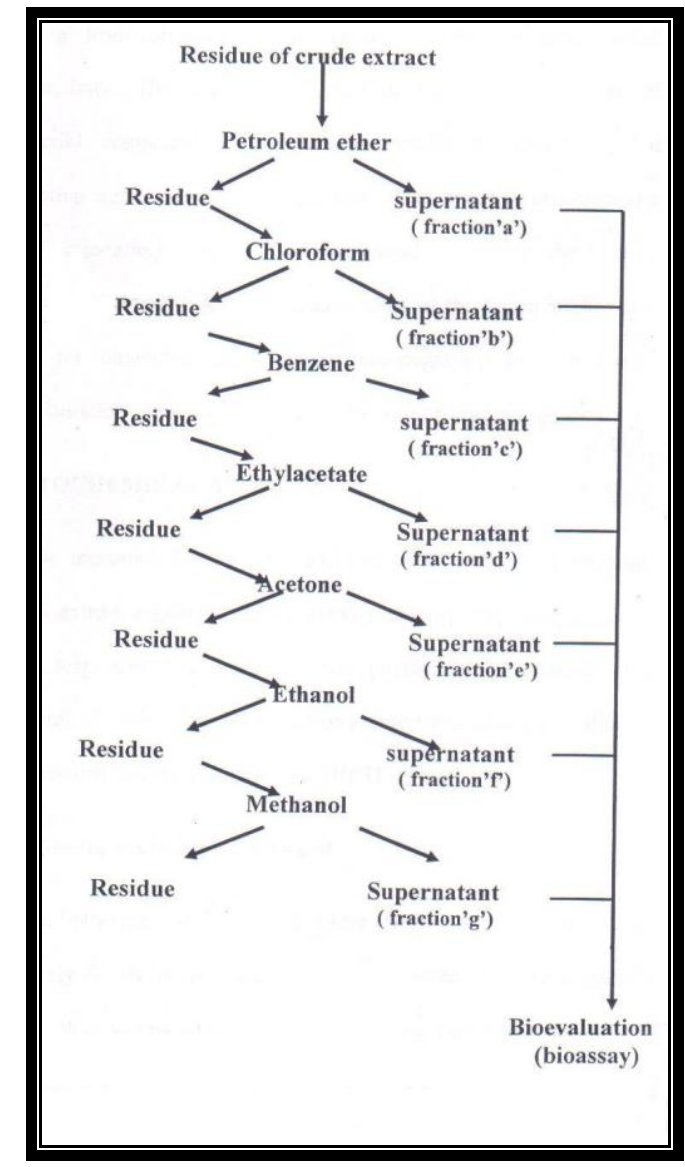

Figure 1. Flow chart for fractionation of stem ethanol extract of E. agallocha.

Table 1. Microorganisms selected for the study and media used.

\begin{tabular}{|c|c|c|c|c|c|}
\hline Sr. No. & Microorganism & Type & Source & Media & $\begin{array}{l}\text { Incubation } \\
\text { temperature }\end{array}$ \\
\hline 1 & Aspergillus fischeri & Fungi & $\begin{array}{l}\text { NCIM } \\
517\end{array}$ & $\begin{array}{l}\text { Potato } \\
\text { Dextrose agar }\end{array}$ & RT \\
\hline 2 & Candia albicans & Fungi & $\begin{array}{l}\text { NCIM } \\
3471\end{array}$ & $\begin{array}{l}\text { Potato } \\
\text { Dextrose agar }\end{array}$ & RT \\
\hline 3 & Escherichia coli & $\begin{array}{l}\text { Gram - ve } \\
\text { Bacteria }\end{array}$ & NCIM 2576 & Nutrient agar & $37^{\circ} \mathrm{C}$ \\
\hline 4 & Klebsiella pneumoniae & $\begin{array}{l}\text { Gram - ve } \\
\text { Bacteria }\end{array}$ & NCIM 5082 & Nutrient agar & $37^{\circ} \mathrm{C}$ \\
\hline 5 & Staphylococcus aureus & $\begin{array}{l}\text { Gram + ve } \\
\text { Bacteria }\end{array}$ & $\begin{array}{l}\text { NCIM } \\
5021\end{array}$ & Nutrient agar & $37^{\circ} \mathrm{C}$ \\
\hline 6 & Bacillus cereus & $\begin{array}{l}\text { Gram + ve } \\
\text { bacteria }\end{array}$ & $\begin{array}{l}\text { NCIM } \\
2322\end{array}$ & Nutrient agar & RT \\
\hline 7 & Salmonella typhimurium & $\begin{array}{l}\text { Gram - ve } \\
\text { Bacteria }\end{array}$ & NCIM 2501 & Nutrient agar & $37^{\circ} \mathrm{C}$ \\
\hline
\end{tabular}

NCIM: National Collection of Industrial Microorgansims, NCL, Pune, India. $\quad$ RT- Room Temperature 


\section{Anticancer activity on pancreatic cancer cell lines}

Cell lines and culture maintenance conditions The human pancreatic cancer cell lines Miapaca2, PANC-1, Capan-1 and BxPC-3 were purchased from the American Type Culture Collection (MD, USA). All the chemicals and media were purchased from Sigma, USA except for FBS which was from Hyclone, USA. Miapaca-2 and BxPC-3 were grown in RPMI1640 culture medium, Panc-1 in Dulbecco's Modified Eagle's Medium, Capan-1 in Iscove's Modified Dulbecco's Medium. Each medium was supplemented with $10 \%$ heat inactivated FBS, 2\% L-glutamine (200 mM) and $1 \%$ penicillin-streptomycin. Cells were grown as a monolayer culture at $37^{\circ} \mathrm{C}$ in a humidified $5 \%$ $\mathrm{CO}_{2}$ incubator.

\section{In vitro cytotoxicity assay (MTS assay)}

Cells were seeded at a density of $3 \times 10^{4}$ cells per well in 96-well plates. The following day, $20 \mu 1$ of culture medium (negative control) or medium containing the test compound was added to the wells. Each concentration was plated in triplicate. $48 \mathrm{~h}$ of drug exposure, the effect on the cell viability was measured using MTS cell proliferation assay (Cory et al., 1991). $20 \mu \mathrm{l}$ of non- radioactive MTS reagent (Promega, USA) was added to each well. Cells were incubated further to allow for colour development before the absorbance values were read at $490 \mathrm{~nm}$ using a microplate reader. The percentage cytotoxicity based on control treatment (untreated- negative control) was calculated and plotted against fraction concentrations. The concentration of $E$. agallocha fraction inducing $50 \%$ inhibition of cancer cells ( $\mathrm{IC}_{50}$ values) was calculated from the cytotoxicity curves.

\section{Chemical characterization of bioactive fraction}

\section{Fourier Transform Infra Red Spectroscopy (FT-IR)}

Bioactive fraction was subjected to crystallization and these crystals were analysed to detect the functional groups by IR spectroscopy. The analysis was carried out at IIT, Mumbai using Fourier Transform Infra Red Spectroscopy (Perkin Elmer Spectrum One spectrometer). A known amount of powdered sample (1-2\%) was mixed with a weighed amount of powdered $\mathrm{KBr}$ and the mixture was subjected to a pressure of several tones in die, to produce a highly transparent disc, which was inserted into the spectrophotometer. Scan range was $450-4000 \mathrm{~cm}^{-1}$.

\section{High Performance Thin layer Chromatography (HPTLC)}

Bioactive fraction was also screened for the presence of phytoconstituents by HPTLC to detect the principle class of secondary metabolite attributed to the activity. $20 \mu \mathrm{l}$ of active fraction was loaded in duplicates on a ready made fluorescent pre-coated silica gel-G aluminum (supplied by MERCK) HPTLC plates and developed using appropriate solvent systems as described by Wagner and Bladt (1996). The analysis was done on Linomat-5 supplied by CAMAG in the Anchrom, R \& D laboratory, Mulund, Mumbai. The resultant chromatograms were illuminated at UV-254 or UV-366 nm or $560 / 580 \mathrm{~nm}$ for the characteristic quenching or fluorescence respectively for the particular class of bioactive compounds. The plates were derivatized and heated if necessary on a HPTLC heater for the detection of the compounds.

\section{RESULTS}

Fraction ' $\mathrm{f}$ ', i.e., the ethanol fraction of crude stem ethanol extract of E. agallocha showed most potent antibacterial activity (Table 2 ) in the bioassay and hence was tested for its anti reverse transcriptase and anticancer activity. This fraction showed $33.7 \%$ inhibition in the anti reverse transcriptase assay which was as good as that of the standard synthetic inhibitor AZT $(35.5 \%)$ (Table 3$)$.

The effects of this fraction of E. agallocha on the growth of various human pancreatic cell lines were tested under in vitro conditions using different concentrations (1, 3, 10, 30 and 100 $\mu \mathrm{g} / \mathrm{ml}$ ) and cell survival after $48 \mathrm{~h}$ of treatment is given in Table 4 . The fraction offered a high degree of inhibition over the growth of two cell lines- Capan-1 and Miapaca-2, which was significantly more than that on the other two cell lines- PANC-1, and BxPC-3 (Figure 2). The $\mathrm{IC}_{50}$ values were calculated to be $4 \mu \mathrm{g} / \mathrm{ml}$ and 7 $\mu \mathrm{g} / \mathrm{ml}$ for Capan-1 and Miapaca-2 respectively (Table 5). The inhibition was found to be dose dependent with greater inhibition at the highest concentration $(100 \mu \mathrm{g} / \mathrm{ml})$. The cytotoxic activity was compared with the effect of flavopiridol (positive control), which showed significant cytotoxic activity on all the four cell lines with $\mathrm{IC}_{50}$ values in the range of 0.03 to $0.11 \mu \mathrm{g} / \mathrm{ml}$. 
Table 2. Activity guided fractionation of soxhlet stem ethanol extract of E. agallocha.

\begin{tabular}{|c|c|c|c|c|c|c|c|}
\hline Organism & $\begin{array}{l}\text { Pet. } \\
\text { Ether } \\
\text { Fract. } \\
\text { 'a' }\end{array}$ & $\begin{array}{l}\text { Chloroform } \\
\text { Fract. } \\
\text { 'b' }\end{array}$ & $\begin{array}{l}\text { Benzene } \\
\text { Fract. } \\
\text { 'c' }\end{array}$ & $\begin{array}{l}\text { Acetone } \\
\text { Fract. } \\
\text { 'd' }\end{array}$ & $\begin{array}{l}\text { Ethyl } \\
\text { acetate } \\
\text { Fract. } \\
\text { 'e' } \\
\end{array}$ & $\begin{array}{l}\text { Ethanol } \\
\text { Fract. } \\
\text { 'f' }\end{array}$ & $\begin{array}{l}\text { Methanol } \\
\text { Fract. } \\
\text { 'g' }\end{array}$ \\
\hline E. coli & - & - & - & + & ++ & +++ & ++ \\
\hline B. cereus & - & - & - & ++ & ++ & +++ & ++ \\
\hline Candida albicans & - & - & - & ++ & ++ & +++ & ++ \\
\hline Aspergillus fischeri & & & & + & + & ++ & + \\
\hline $\begin{array}{l}\text { Klebsiella } \\
\quad \text { pneumoniae }\end{array}$ & - & - & - & + & + & ++ & ++ \\
\hline S. aureus & - & - & - & + & + & ++ & ++ \\
\hline $\begin{array}{l}\text { Salmonella } \\
\quad \text { typhimurium }\end{array}$ & - & - & - & + & + & ++ & ++ \\
\hline
\end{tabular}

Table 3. Anti-reverse transcriptase activity of ethanol fraction of stem ethanol extract of E. agallocha.

\begin{tabular}{lc}
\hline Sample & $\begin{array}{l}\text { \% Reverse transcriptase (RT) } \\
\text { inhibition }\end{array}$ \\
\hline $\begin{array}{l}\text { Bioactive fraction Stem ethanol } \\
\text { extract of E. agallocha }\end{array}$ & 33.7 \\
AZT drug $(8 \mu \mathrm{g} / \mathrm{ml})$ (positive control) & 35.5 \\
Ethanol (negative control) & NIL \\
\hline
\end{tabular}

Table 4. Cytotoxic activity of ethanol fraction of stem ethanol extracts of different Concentrations of E. agallocha on human pancreatic cancer cell lines after $48 \mathrm{~h}$ of treatment.

\begin{tabular}{ccccc}
\hline \multirow{2}{*}{$\begin{array}{c}\text { Conc. of extract } \\
(\boldsymbol{\mu g} / \mathbf{m l})\end{array}$} & \multicolumn{4}{c}{ \% growth inhibition } \\
\cline { 2 - 4 } & Capan- 1 & Miapaca- 2 & PANC- 1 & BxPC-3 \\
1 & 0 & 8 & 0 & 0 \\
3 & 0 & 19 & 0 & 0 \\
10 & 58 & 59 & 0 & 0 \\
30 & 73 & 73 & 0 & 0 \\
100 & 81 & 79 & 35 & 36 \\
\hline
\end{tabular}

Table 5. Mean $\mathrm{IC}_{50}$ values of ethanol fraction of stem ethanol extract of E. agallocha in human pancreatic cancer cell lines.

\begin{tabular}{lcc}
\hline Cell line & Mean $\mathbf{I C}_{\mathbf{5 0}}(\boldsymbol{\mu g} / \mathbf{m l})$ \\
\hline & E. agallocha ethanol extract & Flavopiridol \\
Capan-1 & 4 & 0.08 \\
Miapaca & 7 & 0.04 \\
PANC-1 & $>100$ & 0.03 \\
BxPC-3 & $>100$ & 0.11 \\
\hline (Significant dose effects were observed in two cancer cell lines Capan-1 and Miapaca-2 compared to \\
PANC-1 and BxPC-3, $(\mathrm{P}<0.005)$ with a lower cell viability observed at the highest treatment concentrations)
\end{tabular}


Miapaca-2
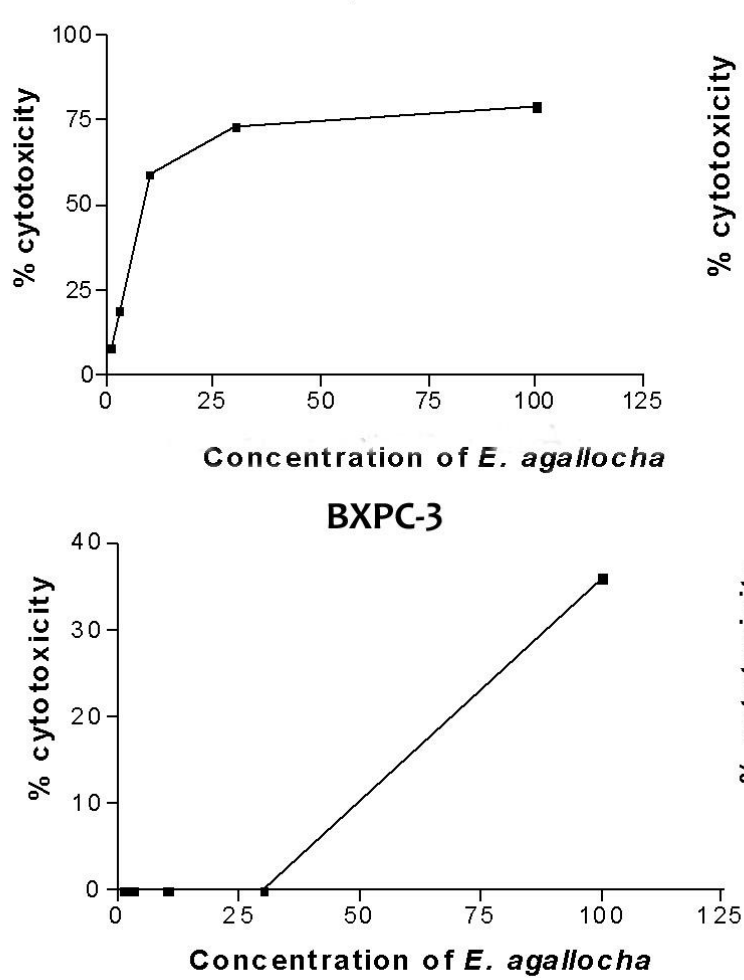

Capan-1
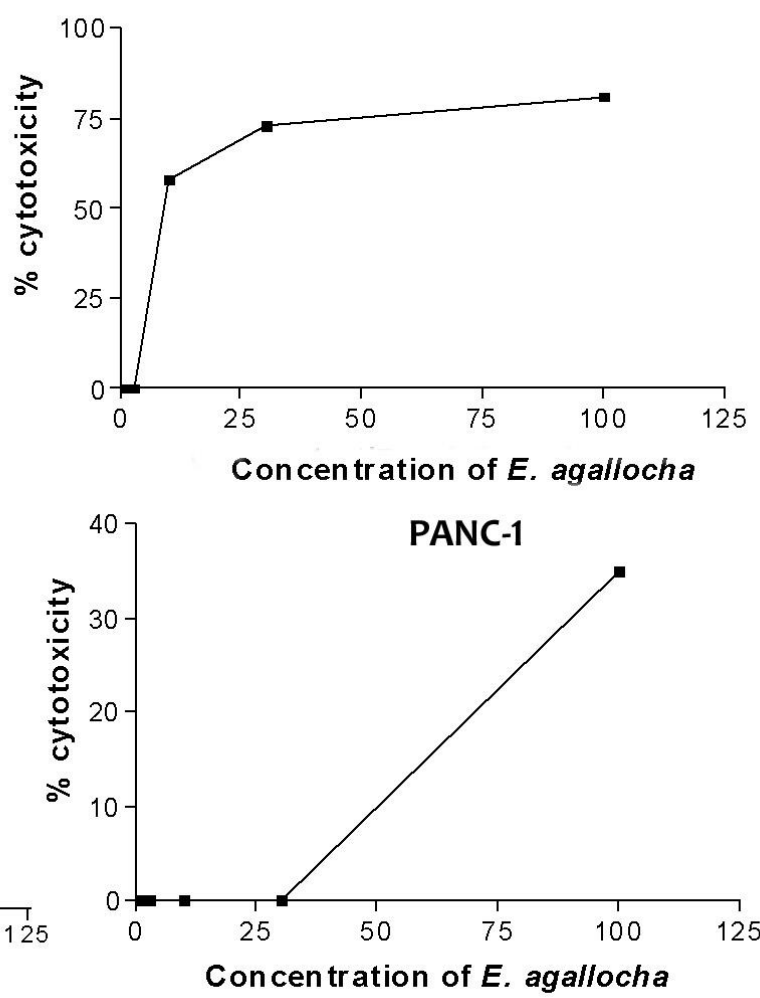

Figure 2. Growth inhibitory effect of ethanol fraction of stem ethanol extract of E. agallocha on human pancreatic cancer cell lines.

Infra red spectrum of bioactive fraction analyzed for detecting functional groups showed the presence of a peak at $3331.59 \mathrm{~cm}^{-1}$ indicating presence of bonded -OH (hydroxyl) group containing compounds in it. The spectrum also showed the presence of two humps at 2927.7 $\mathrm{cm}^{-1}$ and $2098.45 \mathrm{~cm}^{-1}$ indicating - CH Stretching. It further showed a hump 1618.01 $\mathrm{cm}^{-1}$ indicating compounds with $\mathrm{C}=\mathrm{C}$ Stretching. The spectrum then showed two humps at $1515.22 \mathrm{~cm}^{-1}$ and $1404.89 \mathrm{~cm}^{-1}$ indicating Methyl C $-\mathrm{H}$ Stretching. Infra red spectrum of methanol fraction A finally showed series of humps between $1240.15 \mathrm{~cm}^{-1}$ to $639.50 \mathrm{~cm}^{-1}$ indicating compounds with $\mathrm{C}-\mathrm{C}$ Stretching.

Bioactive stem fraction of E. agallocha was analyzed for the presence of all the ten major classes of bioactive compounds viz. Alkaloids, anthraglycosides, arbutin, bitter drugs, cardiac glycosides, coumarins, essential oils, flavonoids, saponins and valeportraites. The fraction showed presence of seven peaks in case of cardiac glycosides and three peaks in case of saponins. Any other class of phytoconstituents could not be detected in the bioactive fraction.

\section{DISCUSSION}

Mangrove designates an intertidal wetland ecosystem which proliferates luxuriantly in the intertidal area of low lying coasts and river estuaries, deltas, backwaters and lagoons throughout the low lying tropical and subtropical latitudes. Mangrove plants can produce metabolites and toxins that are unique to these plants and there have been certain examples in the recent years, which suggest that they may be a source of novel compounds. These are used clinically to develop a variety of drugs for the treatment of diseases.

Current therapy for human immunodeficiency virus (HIV) infection relies primarily on the administration of anti-retroviral nucleoside analogues, either alone or in 
combination with HIV-protease inhibitors. Although nucleoside analogues, such as AZT have been approved for clinical use in HIV-1 infection, there are substantial toxic side effects associated with their use, and complete inhibition of viral replication is not achieved. Recently, significant progress has been made towards the development of natural and synthetic agents that can directly inhibit HIV replication or its essential enzymes. Natural product RT inhibitors, such as benzophenanthridine (Ono et al., 1988) and protoberberine (Sethi, 1979), alkaloids, flavonoids (Sethi, 1983; Spedding et al., 1989), a variety of other compounds with phenolic hydroxy groups (Ono et al., 1990; Kakiuchi et $a l ., 1985)$ and certain antibiotics (Nakane et al., 1991), were found to inhibit HIV-1 RT (as well as HIV-2 RT) with similar potency. Previous studies by Premanathan et al., (1996) showed that mangrove species such as Rhizophora mucronata, Rhizophora apiculata, Ceriops decandra, Rhizophora apiculata, Rhizophora lamarckii exhibit in vitro anti HIV activity. In this study, we revealed the potent anti HIV activity of the active fraction of stem ethanol extract of E. agallocha, which showed significant anti reverse transcriptase activity as potent as the standard approved drug AZT.

Several reports are available on the anticancer activity of compounds isolated from different mangrove species. Mangroves species such as Acanthus illicifolius, Bruguiera sexangula, Morinda citrifolia, Terminalia catappa, Ecteinacidia turbindate have been shown to produce compounds that show strong activity against a variety of carcinomas, melanomas and lymphomas (Bandarnayake, 2002). Extracts of B. sexangula bark were active against two tumors, Sarcoma 180 and Lewis Lung Carcinoma (Loder and Russell, 1969). Jongsuvat et al., (1981) also found that the extracts of $A$. illicifolius were not toxic to experimental mice but displayed significant anti leukemic activity. However, anticancer activity of E. agallocha has not been explored sufficiently. Subhan et al., (2008a, 2008c) had indicated that ethanolic stem extract of $E$. agallocha has potent antioxidant and antibacterial activity. In the present study stem ethanol extract was subjected to activity-guided fractionation and its bioactive fraction (ethanol fraction) was tested for its anticancer and anti reverse transcriptase activity. The greatest cytotoxic effect of this fraction was observed on two out of four pancreatic cancer cell linesCapan-1 and Miapaca-2. The cytotoxic activity increased in a dose-dependent manner after $48 \mathrm{~h}$ of exposure. The $\mathrm{IC}_{50}$ values calculated by plotting cytotoxicity curves were $4 \mu \mathrm{g} / \mathrm{ml}$ and 7 $\mu \mathrm{g} / \mathrm{ml}$ respectively which were $<20 \mu \mathrm{g} / \mathrm{ml}$ and hence the extract can be considered as 'active' according to National Cancer Institute's guidelines (Boyd, 1997).

In conclusion, activity guided ethanol fraction of stem ethanol extract of E. agallocha has significant anti reverse transcriptase activity. It also exhibits concentration-dependent anticancer activity on human pancreatic cancer cell lines. HPTLC fingerprinting indicated presence of only couple of phytochemical groups viz. cardiac glycosides and saponins in the bioactive fraction indicating that these groups must be responsible for attributing the activity. Further molecular studies are underway to elucidate the mechanism(s) of action of these extracts on cancer cells. Thus, the stem extracts of E. agallocha has the potential to be developed as an anti HIV and anticancer drug.

\section{ACKNOWLEDGEMENTS}

Authors are indebted to Dr. U. A. Jadhav of University Department of Life Sciences for her encouragement and authorities at Haffkine Research Institute, Indian Institute of Technology (IIT) and Anchrom R \& D, Mumbai for providing facilities for reverse-transcriptase inhibition as say, FT-IR analysis and HPTLC analysis respectively.

\section{REFERENCES}

Bandaranayke, W. M. (1998). Traditional and medicinal uses of mangroves. Mangroves and salt marshes, 2(3): 133-148.

Bandarnayake, W.M. (2002). Bioactivities, bioactive compounds and chemical constituents of mangrove plants. Wetlands Ecological Management 10: 421-452.

Boyd, M.R. (1997). The NCI in vitro anticancer drug discovery screen. In: B. Teicher (Ed), Anticancer drug development guide; preclinical screening, clinical trials and approval, Humana Press, Totowa Pp.30.

Cochrane, C.B., Nair, P.K., Melnick, S.J., Resek, A.P. and Ramachandran, C. (2008). Anticancer effects of Annona glabra plant extracts in human leukemia cell lines. Anticancer Research 28: 965-972.

Cory, A.H., Owen, T. C., Barltrop, J. A. and Cory, JG. (1991). Use of an aqueous soluble tetrazolium/ formazan assay for cell growth 
assays in culture. Cancer Communications 3(7): 207-212.

Cragg, G. M. and Newman, D. J. (2005). Plants as a source of anti-cancer agents. Journal of Ethnopharmacolgy 100: 72-79.

Erickson, K.L., Beutler, J.A., Cardellina, J.H., McMahon, J.B., Newman, J.D. and Boyd, M.R. (1995). A novel phorbol ester from Excoecaria agallocha, Journal of Natural Products, 58: 769- 772.

FAO (2007). The World's Mangroves 19802005. In: FAO Forestry Paper No. 153. Food and Agriculture Orgnization of United Nations, Rome, Italy. Pp. 1-89.

Ghani, A. (2003). Medicinal Plants of Bangladesh. $2^{\text {nd }}$ edition. The Asiatic Society of Bangladesh, Pp. 228-229.

Jayaweera, D. M. A. (1980). Medicinal plants used in Ceylon. J. Natl. Sci. Coun. Sri Lanka 2: 214-215.

Jongsuvat, Y. (1981). Investigation of anticancer from Acanthus illicifolius. MS thesis. Chulalongkorn University, Bangkok, Thailand.

Kakiuchi, N., Hattori, M., Namba, T., Nishizawa, M., Yamagishi, T. and Okuda, T. (1985). Inhibitory effect of tannins on reverse transcriptase from RNA tumor virus. Journal of Natural Products 48: 614-621.

Kirchner, J.G. (1978). Developing the Chromatogram. In: Thin Layer Chromatography. ( $2^{\text {nd }}$ Edition) Techniques of Chemistry, John Wiley and Sons, XIV. Pp. 250-253.

Lin, Y-M., Anderson, H., Flavin, M.T., YeahHui, S., Mata-Greenwood, P., Pengsuparp, T., John, M., Pezzuto Raymond, F., Schinazi Stephen, H. and Chen, H-C. (1997). In Vitro anti-HIV activity of biflavonoids isolated from Rhus succedanea and Garcinia multiflora. Journal of Natural Products 60(9): 884-888.

Loder, J.W. and Russell, G.B. (1969). Tumor inhibitory plants. The alkaloids of Bruguiera sexangula and Bruguiera exaristata (Rhizophoraceae). Australian Journal of Chemistry 22: 1271-1275.

Mekkawy, S.L., Meselhy, M.R., Hafez, A.A.M.A., Nakamura, N., Hattori, M., Kawahata, T. and Otake, T. (2002). Inhibition of cytopathic effect of Human Immunodeficiency Virus Type-1 by various phorbol derivatives. Chemical and Pharmaceutical Bulletin 50 (4): 523-329.

Michaud, D.S. (2004). Epidemiology of pancreatic cancer. Minerva Chirurgica 59(2): 99-111.

Morgany, T., Sivasothi, N., Murphy, D.H., Ng, P. K. L., Soong, B. C., Hugh, T., Tan, W. and
Tan, T.K. (1999). The Ecosystem and Plant Diversity. In: P.K. L. Ng and N. Sivasothi (eds). A Guide to the Mangroves of Singapore, Pp. 111-112.

Nakane, H., Arisawa, M., Fujita, A., Koshimura, S. and Ono, K. (1991). Inhibition of HIVreverse transcriptase activity by some phloroglucinol derivatives. FEBS Letters 286: 83-85.

Ohigashi, H., Katsumata, H., Kawazu, K., Koshimizu, K. and Mitsui, T. (1974). A piscicidal constituent of Excoecaria agallocha. Agric. Biol. Chem. 38(5): 10931095

Ono, K., Nakane, H. and Fukushima, M. (1988). Differential inhibition of various deoxyribonucleic and ribonucleic acid polymerases by suramin. European Journal of Biochemistry 172: 349-353.

Ono, K., Nakane, H., Fukushima, M., Chermann, J. C. and Barre-Sinoussi, F. (1990). Differential inhibitory effects of various flavonoids on the activities of reverse transcriptase and cellular DNA and RNA polymerases. European Journal of Biochemistry 190: 469-476.

Patra, J. K., Mohapatra, A.D., Rath, S. K., Dhal, N. K. and Thatoi, H. (2009). Screening of antioxidant and antifilarial activity of leaf extracts of Excoecaria agallocha L. International Journal of Integrative Biology, 7(1): 9-15.

Pengsuparp, T., Cai, L., Fong, H. H. S., Kinghorn, A. D. and Pezzuto, J. M. (1994). Pentacyclic triterpenes derived from Maprounea africana are potent inhibitors of HIV-1 reverse transcriptase. Journal of Natural Products 57(3): 415-418.

Pengsuparp, T., Cai, L. H., Constant, H., Fong, H. H. S., Lin, L.-Z., Kinghorn, A.-D., Pezzuto, J. M., Cordell, G. A., Ingolfsdottir, K., Wagner, H. and Hughes, S. H. (1995). Mechanistic evaluation of new plant-derived compounds that inhibit HIV-1 reverse transcriptase. Journal of Natural Products 58(7): 1024-1031.

Pengsuparp, T., Serit, M., Hughes, S. H., Soejarto, D. D. and Pezzuto, J. M. (1996). Specific inhibition of Human Immunodeficiency Virus Type 1 reverse transcriptase mediated by Soulattrolide, a coumarin isolated from the latex of Calophyllum teysmannii. Journal of Natural Products 59(9): 839-842.

Prakash, S., Khan, M., Khan, H. and Zaman, A. (1983). A piperidine alkaloid from Excoecaria agallocha. Phytochemistry, 22: 1836-1837. 
Premanathan, M., Nakashima, H., Kathiresan, K., Rajendran, N. and Yamatomo, N. (1996). In vitro anti-human immunodeficiency virus activity of mangrove plants. Indian Journal of Medical Research 103: 278-81.

Ravikumar, S., Muthuraja, M., Sivaperumal, P. and Gnanadesigan, M. (2010). Antibacterial activity of the mangrove leaves Excoecaria agallocha against selected fish pathogens. Asian Journal of Medical Sciences, 2(5): 211 213.

Sethi, M.L. (1979). Inhibition of reverse transcriptase activity by benzophenanthridine alkaloids. Journal of Natural Products 42(2): 187-196.

Sethi, M.L. (1983). Enzyme inhibition VI: Inhibition of reverse transcriptase activity by protoberberine alkaloids and structure-activity relationships. Journal of Pharmaceutical Science 72: 538-541.

Shoeb, M. (2006). Anticancer agents from medicinal plants. Bangladesh Journal of Pharmacology 1: 35- 41.

Singh, H.S. (2000). Mangroves in Gujarat: Current status and strategy for Conservation. Gujarat Ecological Education and research (GEER) Foundation, Gandhinagar, India.

Spedding, G., Ratty, A. and Middleton, E. Jr. (1989). Inhibition of reverse transcriptases by flavonoids. Antiviral Research 12: 99-110.

Spooner, D. F. and Sykes, G. (1972). Laboratory assessment of antibacterial activity. In: J. R. Norris and D. W. Ribbons (Eds), Methods in Microbiology Vol. 78, Academic Press, London, Pp. 211-276.

Subhan, N., Alam, A., Ahmed, F. and Shahid, I. Z. (2008a). Antinociceptive and gastroprotective effect of the crude ethanolic extracts of Excoecaria agallocha Linn. Turkish Journal of Pharmaceutical Sciences 5 (3): 143-154.

Subhan, N., Alam, M. A., Ahmed, F., Shahid, I. J., Nahar, L. and Sarker, S. D. (2008b). Bioactivity of Excoecaria agallocha. Brazilian Journal of Pharmacognosy 18 (4): 521-526.
Subhan, N., Alam, M. A., Ahmed, F., Awal, M. A., Nahar, L. and Sarker, S.D. (2008c). In vitro antioxidant property of the extract of Excoecaria agallocha (Euphorbiaceae) DARU; 16 (3): 149-154.

Sun, H.-D., Qiu, S.-X., Lin, L.-Z.,Wang, Z. Y., Lin, Z. W., Pengsuparp, T., Pezzuto, J. M., Fong, H. H. S., Cordell, G. A. and Farnsworth, N. R. (1996). Nigranoic acid, a triterpenoid from Schisandra sphaerandra that inhibits HIV-1 reverse transcriptase. Journal of Natural Products 59(5): 525-527.

Thirunavukkarasu, P., Ramkumar, L. and Ramanathan, T. (2009). Anti-ulcer activity of Excoecaria agallocha bark on NSAIDinduced gastric ulcer in albino rats. Global Journal of Pharmacology, 3(3): 123-126.

UNESCO (1981). Bibliography on mangrove research, 1600-1975. Rollet, B. ed. printed by Information retrieval limited, London for UNESCO, Paris, pp. 1-479.

Upur, H., Yusup, A., Baudrimont, I., Umar, A., Berke, B., Yimit, D., Lapham, J. C., Creppy, E. and Moore, N. (2008). Inhibition of cell growth and cellular protein, DNA and RNA synthesis in human hepatoma (HepG2) cells by ethanol extract of abnormal Savda Munziq of traditional Uigher medicine. Evidence Based Complementary and Alternative Medicine (0): nen062v1-nen062.

Vadlapudi, V., Bobbarala, V., Penumajji, S. and Naidu, K. C. (2009). Excoecaria agallocha L. antimicrobial properties against important pathogenic microorganisms. International Journal of ChemTech Research 1(4): 865-867.

Wagner, H. and Bladt, S. (1996). Plant drug analysis: A thin layer chromatography Atlas, $2^{\text {nd }}$ Edition, berlin, Springer Pp. 349-364.

Wiriyachitra, P., Hajiwangon, H., Boanton, P., Adolf, W., Opterkuch, H. S. and Hecker, E. (1985). Investigations of Medicinal Plants of Euphorbiaceae and Thymelaeaceae Occurring and Used in Thailand; II. Cryptic Irritants of the Diterpene Ester Type from Three Excoecaria species L. Planta Medica 51(5): 368-371. 